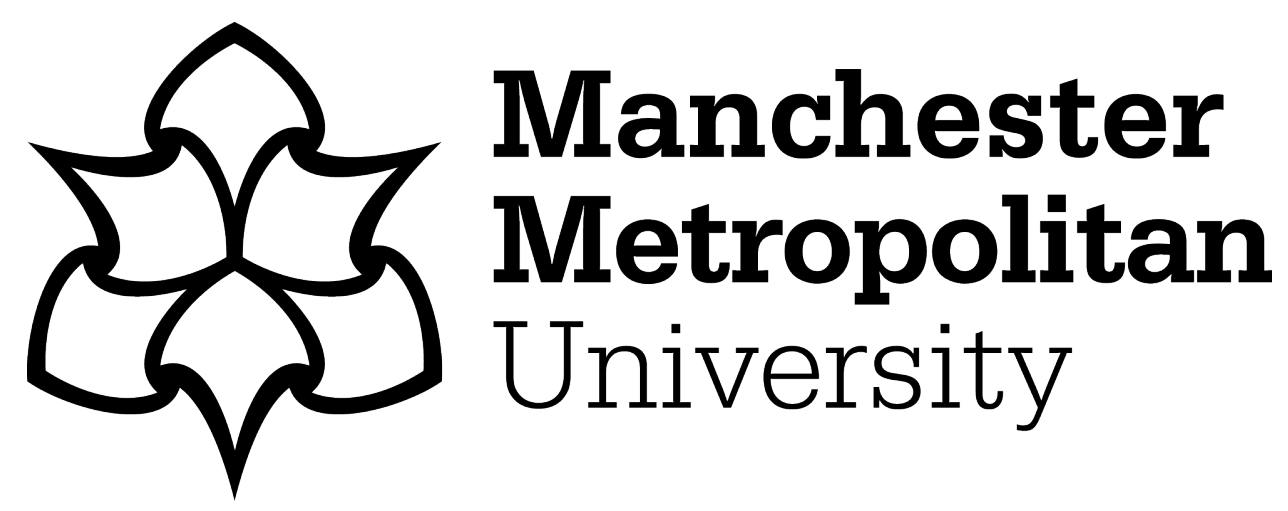

Atkinson, Carol ORCID logoORCID: https://orcid.org/0000-0002-3795-7442 and Pareit, Els (2019) Psychological Contracts of International Business Travellers. Personnel Review, 48 (7). pp. 1701-1715. ISSN 0048-3486

Downloaded from: https://e-space.mmu.ac.uk/622537/

Version: Accepted Version

Publisher: Emerald

DOI: https://doi.org/10.1108/PR-06-2016-0142

Please cite the published version 
Personnel Review

emerald

PUBLISHING

Personnel Review

PSYCHOLOGICAL CONTRACTS OF INTERNATIONAL BUSINESS TRAVELLERS

\begin{tabular}{|r|l|}
\hline Journal: & Personnel Review \\
\hline Manuscript ID & PR-06-2016-0142.R1 \\
\hline Manuscript Type: & Research Article \\
\hline Keywords: & $\begin{array}{l}\text { Psychological Contract, International Business Traveller, Transactional, } \\
\text { Relational, Belgium }\end{array}$ \\
\hline Methodologies: & Qualitative \\
\hline \multicolumn{2}{|l}{} \\
\hline
\end{tabular}

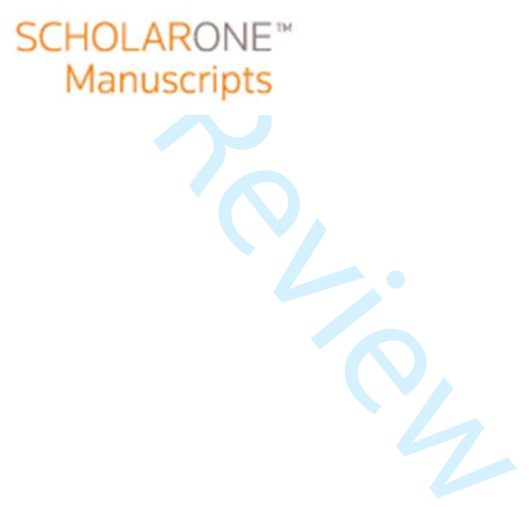




\section{PSYCHOLOGICAL CONTRACTS OF INTERNATIONAL BUSINESS TRAVELLERS}

\section{Introduction}

Since the late 1980s, the global economy has grown rapidly with an associated expansion in the field of International Human Resource Management (IHRM) (Collings et al., 2007). While IHRM's focus has shifted from managing staff expatriation to broader organisational, contextual and HR-related issues (Björkman et al., 2012, Björkman and Welch, 2015), much research remains preoccupied with traditional, long-term international assignments. Only recently there has been a growing research interest in alternative forms of international assignments (Mäkelä et al., 2017, Pate and Scullion, 2017). Here we focus on an emergent, non-traditional form of international employee, the international business traveller (IBT). We define an IBT as a professional who works across countries for business purposes on a regular basis and for a maximum of consecutive three weeks per assignment (Shaffer et al., 2012). We explore IBT employment relationships using a psychological contract framework which explores employee perceptions of their own and their employer's obligations (Pate and Scullion, 2010), provides a fruitful construct for analysis and explanation (Rousseau, 1995) and offers a mechanism for effectively working to attract and retain scarce employees (Rodwell et al., 2015). There are no existing studies of IBT psychological contracts and we develop in-depth understanding of how Belgian IBTs experience and interpret their psychological contracts. Belgium is an interesting context as it plays a 'pivotal role' within the global economy (Sleeuwaegen and Peeters, 2012: 7), assuming a strategic location on the north-western side of Europe and being one of the most globalised countries 
in the world (OECD, 2013). Our research makes a number of important contributions. First empirically to IHRM, in developing understanding of an emergent form of international employee, the IBT. Second, to psychological contract theory in developing understanding of contract nature. Finally, to practice in developing understanding of how to manage the valuable strategic resource that is the IBT.

The paper is organised as follows: first we discuss extant research on IBTs and psychological contract, synthesising these to establish our research focus; second, we present our research methods and third, we report the findings. Finally, we discuss and draw conclusions on the contributions and implications our research.

\section{International Business Travel(lers)}

Globalisation not only creates an increasingly complex environment, it also requires more internationally-prepared workers, occasioning new forms of international employment (Harvey et al., 2010). Alongside traditional, longterm expatriate assignments, short-term international missions are emerging that meet organisational operational objectives and individual career objectives within today's dynamic business environment (Mayerhofer et al., 2004, Collings et al., 2007). Traditional expatriate assignments require the employee and family (where present) to move countries for work purposes, usually for over a year, to address a specific task or organizational goal (Petrovic et al., 2000). IBTs, by contrast, are professionals for whom regular international travel for periods of up to three consecutive weeks, without their family, constitutes an 'essential component' of their work (Welch and Worm, 
2006: 284, Shaffer et al., 2012). IBTs tend to be utilised for specialised and complex tasks, often in challenging or dangerous environments, that occur intermittently and determine the duration of visit (Collings et al., 2015). The flexibility which characterises IBT assignments, avoiding the need for permanent relocation, is often more acceptable to employees than longerterm expatriate assignments (Tahvanainen et al., 2005). It also benefits organisations, as it does not incur the huge financial and other costs associated with employee and family/spouse relocation (Welch et al., 2007). IBT assignments are thus attractive to employees, cost effective and allow companies to respond more swiftly than with traditional expatriate placements (Tahvanainen et al., 2005).

Understanding of IBTs is, however, lacking (Welch and Worm, 2006, Welch et al., 2007), against a backdrop in which there is no widely agreed classification of various short-term international work experiences (Shaffer et al., 2012). This is a serious omission given the increasing prevalence of international business travel in the modern global economy (Beaverstock et al., 2010). Drawing on Welch and Worm (2006), we suggest that IBTs form a diverse group, perhaps more diverse than traditional expatriates. Assignments can typically include project-work, maintaining client and supplier engagement/relations, monitoring business development, skills transfer, participation in meetings or conferences, management development and management control (Mayerhofer et al., 2004). IBTs have the capacity to act as 'powerful knowledge transfer agents', implying that they are 'at the heart of international business' and play an essential, strategic role within the survival and development of globally operating companies (Welch et al., 
2007:180). Critical to assignment success is an IBT's capacity for selfmanagement, especially in relation to work, cultural issues and planning of leisure time (Mayerhofer et al., 2004). As frequent business travel disturbs everyday routines (Makela et al., 2015), stress both to the travellers and their families (Baker and Ciuk, 2015, Mäkelä et al., 2017), jet lag and health issues are common problems (Espino et al., 2002). Thus, to maximise the strategic potential of IBTs, organisations must understand how to manage and support non-standard international employment (Demel and Mayrhofer, 2010). Yet many find themselves at the beginning of a steep learning curve or in 'organisational silence' where management of IBT assignments are concerned (Tahvanainen et al., 2005: 671, Demel and Mayrhofer, 2010). Our research aims to develop understanding of IBT employment relationship, using a psychological contract framework, to support this management process.

\section{Psychological Contracts}

A psychological contract reflects the perceptions of mutual obligations to each other held by the two parties in the employment relationship, the organisation and the employee' (Herriot et al., 1997:151). Since its first formal introduction in the 1960's, the concept has been a prominent part of human resource management and its related organisational discourse (Conway and Briner 2009). Given the perceptual and socially constructed nature of the contract, however, it is neither possible nor advisable to establish 'the' content of the psychological contract, that is, one set of obligations that holds good in all situations (Authors). A wide array of possible obligations has been identified and we discuss these in more detail 
below, noting here that these may differ according to organisational setting and across nations or cultures (Rousseau and Schalk, 2000). Despite this, psychological contract theory represents a useful framework for understanding workplace relationships and developing insights on how to address employee (here IBTs) perceived obligations and those of their employer (Guest, 1998). While some have challenged the construct as a vague 'container concept of questionable value' (Guest, 1998: 650), its basic premise of reciprocal social exchange holds good (Coyle-Shapiro and Conway, 2010, Conway and Briner, 2009). Lack of research and clarity on content is not considered problematic here as this is inherent to the reality of organisational experience (Tetrick, 2010). Rather, our focus is the nature of psychological contract content (Agarwal and Gupta, 2018) which reflects the distinction between contract exchange types, that is, transactional or relational (MacNeil, 1985).

Transactional contracts are specific economic, monetisable exchanges between parties over a finite, typically short, term. They are characterised by competitive wage rates and the absence of long-term commitments (Robinson et al., 1994). Terms and conditions tend to be objectifiable and remain static during a specified period of time (Chambel et al., 2016). Relational contracts, on the contrary, imply open-ended, less specific agreements that establish and maintain a relationship involving both monetisable and non-monetisable exchanges and emotional investment from both employees and employers (Robinson et al., 1994). While a useful heuristic, relational/transactional distinctions are far from clear cut (Conway and Briner, 2009) with many arguing that to categorise an entire contract is 
too blunt an approach (Authors). Rather than polar opposites, relational and transactional contracts may co-exist (Conway and Briner, 2009) or be viewed along a continuum (Coyle-Shapiro and Parzefall, 2008). A more nuanced approach is to consider categorisation of obligations within contract content, rather than the contract itself. Even here it is not always clearcut how particular obligations are best categorised (Authors). We draw on our earlier work (developing that of Robinson et al., 1994), to present categorisation of typical employer and employee obligations (Table 1). This forms the theoretical base of our study and these obligations are explored from the employee perspective.

Table 1 here

We draw on our earlier definition to argue that both parties, employer and employee, have obligations and that these are both transactional and relational in nature. Employers have transactional obligations of advancement, high and merit pay and relational ones of training, job security, development and support. Employees have transactional obligations of giving adequate notice, transfers, not supporting competitors and protecting the organisation, and a minimum stay and relational ones of working overtime and demonstrating loyalty and extra role behaviour. We explore these for Belgian IBTs, considering only the employee perspective of their own and their employer's obligations. A focus on only one party to the relationship is common practice and does not detract from overall understanding (e.g. Rodwell et al., 2015). 
As there are no previous studies of Belgian IBT psychological contracts, we draw on and synthesise existing psychological contract studies of both traditional expatriate employees and Belgian workers. Taking first expatriates, research has traditionally suggested a tendency to more relational contracts than typical employees (Guzzo and Noonan, 1994). This results from the employer's broad sphere of influence over both work and non-work conditions whereby almost all aspects of the expatriate's daily life are affected. This creates a strong emotional bond with the employing organisation. Further, expatriate assignments are typically open-ended employment and offer high autonomy which contributes to their relational nature. This has, however, been contested. Pate and Scullion (2010), for example, evidence that expatriates reflected a relational contract focus in terms of promotion upon return as well as recognition of skills development, but employers adopted a transactional approach reflected in aggressive contract negotiation and offering less organisational support (Pate and Scullion, 2010). Further, existing research pays little attention to the intentions that organisations have towards expatriation, especially in increasingly flexible economies, where more permeable boundaries (between both organisations and countries) are becoming more common (Thomas et al., 2005). Employees become 'boundaryless careerists' (Thomas et al., 2005: 341), adopting a transactional approach whereby "highly qualified mobile professionals who develop their career competence levels and market value through continuous learning and transfer across borders' (Stahl et al., 2009: 92). There are clear parallels here to IBT roles that indicate their contracts will be more transactional than relational in nature. Suggestions of 
a predominantly transactional psychological contract are also allied to a general shift away from relational psychological contracts as changes in the economic environment, such as increased international competition, lower growth, and essential cost reduction amongst companies shift the employment deal onto a more transactional basis (De Meuse et al., 2001). Here employees are supposed to take responsibility for their own career development and commitment to the job or organisation has been replaced by commitment to the specific work performed (Hiltrop, 1996). The transition also involves a more learning oriented and project-based contract focus with reduced consideration to loyalty (Yan et al., 2002) which is particularly relevant given the typically project-based nature of IBT work (Meyskens et al., 2009). Indeed the IBT psychological contract may not be relational in nature given an often short-term rather than a long-term assignment focus (Stahl et al., 2009).

In summary, the IBT psychological contract might be less relational than traditional expatriate contracts. The flexible nature of the IBT employment relationship, the dynamic business context and the impact/input of the individual (and not the employer-employee partnership) on determining the success of the assignments could all be considered as factors strengthening the transactional nature of the contract.

The Belgian context is also an interesting aspect of this study. Belgian psychological contract research indicates a somewhat limited shift towards a more transactional approach (Sels et al., 2000). De Cuyper et al. (2008) evidence both transactional and relational employee and employer obligations, for example, the striving towards individualism and the focus on 
monetary compensation is balanced by the upholding of the collective negotiated rules and the need for security or belonging, despite the clear importance of the financial aspect with employment (Sels et al., 2000). Further insight into Belgian psychological contracts can, indirectly, be found in the work of (Soens et al., 2005). Their research, aimed at charting Belgian careers, demonstrates that the traditional career marked by a relational psychological contract still occupies a dominant role. Belgian employees have a preference for a permanent, stable and full-time employment deal (Soens et al., 2005). The 'old' (relational) psychological contract is thus not entirely 'dead' (Rousseau, 1995: 110). Nevertheless, new, diverse and transactional career-related trends are also evident. A more competitive and broadening market with changing economic circumstances is recognised as driving more transactional and individualistic working relationships (De Meuse et al., 2001, Pate and Scullion, 2010). Societal factors also play a key role, particularly where there is a prevalence of highly educated employees, as in Belgium (Soens et al., 2005). Erosion of the strictly relational and nonindividual career is acknowledged by Vloeberghs et al. (2005) who evidence the ad hoc nature development policy of Belgian companies in relation to their high potential employees. Further, career elements such as attention to performance, marketability and identification with a job (instead of the organisation) appear to be less-developed policy components within Belgian companies. (Van den Brande et al., 2002) likewise remark in their study of Flemish employees that one out of five employees still holds on to an 'old' contract with their employer. The conclusion of the researchers is that the socalled transformation from traditional employment relationships towards 'new deals' is restricted to a very small group of young and highly educated 
professionals (Van den Brande et al., 2002: 174). Given, however, that this reflects typical IBT characteristics, we may expect them to have predominantly transactional contracts.

Current research thus presents a mixed picture of the extent to which Belgian IBT psychological contracts might be relational or transactional in nature. Our study aims to develop understanding of this issue.

\section{Methods}

We adopted an interpretive approach to developing understanding of the nature of (Belgian) IBT psychological contracts, which is appropriate to their socially constructed nature (Authors). Situation with a subjectivistic paradigm serves to expand existing psychological contract research and addresses the 'methodological (quantitative) rut' into which psychological contract research has fallen (Taylor and Tekelab, 2010: 279). Our interpretive approach responds to increasing pressure to focus psychological contract research on individual employment experiences and their complexity (Coyle-Shapiro and Parzefall, 2008). This indicates reliance upon a qualitative research strategy which supports exploration of new, seldom-researched phenomena. We used semi-structured interviews to obtain descriptions of the life world of the IBT participants (Kvale and Brinkmann, 2009). The interview guide adopted was constructed from the extant literature and offered space and flexibility for the interviewees to share their lived experiences (Miles and Huberman, 1994). The flexibility characterising qualitative and interpretive data collection techniques allowed for adjustment of the initial guide to reflect the learning 
process of conducting interviews and the expanded knowledge offered by the respondents (Miles and Huberman, 1994, Kvale and Brinkmann, 2009).

A purposive sampling technique was adopted through which nine participants, two women and seven men, meeting the definitional criteria of an IBT were identified. Contact was made via the networks of one of the authors who works in an environment where IBTs are commonly found. Participant details are outlined below and indicate the job title and age (average 35 years) for each participant as well as their current employer's business activity and the total number of employees working at the firm, with a reference to the location of operation (Table 2). The participants are listed in the order in which they were interviewed, stating their assigned pseudonym.

Table 2 here

The small sample size is acknowledged but the principle of data saturation was followed (Mason, 2010), that is, little new information emerged during the eighth interview and a ninth was conducted to confirm that consistent themes had been established. Data collection ceased at that point. We also draw on others' work on appropriate sample sizes within the context of interpretive research (Smith et al., 2009, Mason, 2010) to argue that our sample size is adequate, particularly that of MacLean et al. (2011) who evidence that data saturation typically occurs within six to 12 interviews. 
Obligations were identified by using a practical set of 'phenomenologically inspired' rules, in particular two of the three approaches proposed by (van Manen, 1990: 92-3) were followed, namely: the selective or highlighting approach and the holistic or sententious approach. The approaches generated both explicit and implicit concepts that were clustered into sub-themes and themes and became apparent through 'dialogue with the text' (van Manen, 1990: 21). In this way, we surfaced 18 employer and employee obligations, although we present only employee (not employer) perceptions of these.

We note the inevitable limitations of our study. It draws on a small number of participants and is highly dependent on their willingness to share views and experiences. Additionally, it is situated only within a Belgian context. Consequently, we do not seek to generalise our findings but representativeness was not our aim and we argue that its absence is unproblematic. On the contrary, the findings allow for exploration of in-depth experiences and rich descriptions of the IBTs involved.

\section{Findings}

As noted, the interviews surfaced 18 obligations within contract content, four employee obligations, 10 employer obligations and four shared by both parties (Table 3). Our analytical focus is on contract nature and space precludes detailed discussion of how this content was established (for further information see Authors). In brief, IBTs perceived themselves to be obligated to conduct certain in-role behaviours (e.g. doing the job well) together with extra-role and proactive role behaviours (e.g. going above and beyond what 
could be reasonably expected within the role). Additionally, IBTs perceived that they owed loyalty to their employers. Turning to employer obligations, IBTs perceived that their employers were obligated to support them (e.g. finding them accommodation during their international travel) and offer them flexibility in work and working patterns. Job content was an important employer obligation, there being an expectation that IBTs would be offered responsible work, the opportunity to travel and varied work assignments. Autonomy was also a vital aspect of job content. Employers were expected to offer development to the IBTs whether this be vertical (promotion), horizontal (secondments to widen experience) or personal. High financial reward was also expected by most of the IBTs. Certain obligations were perceived to be held by both parties. This included social atmosphere and open relations. In the former, a family-like atmosphere was felt to be important and collegiality, respect and trust were core to the psychological contract. Honesty and candour were also central to an effective psychological contract.

Here, we explore in more detail the nature of these obligations. Each is categorised as transactional or relational according to Author's (year) work (see Table 1). Most categorisations were widely agreed, other than support which was presented as transactional by some participants and relational by others. Obligations were predominantly relational in nature, although transactional obligations also featured, supporting the idea that contracts are not wholly transactional or relational, but a combination of sets of obligations which may differ in nature (Coyle-Shapiro and Parzefall, 2008). Given space constraints, we explore in most detail those obligations which provide insight into contrasts with a typical expatriate psychological contract. 
Table 3 here

\section{Employee obligations}

Three of the four obligations identified were relational. Within role behaviour, IBTs perceived that in-role behaviour, doing the standard job they were paid for, was transactional, that is, an economic exchange in which 'the work must be done' (Bill). This is not a new finding (see Sels et al., 2000) but we argue that 'just' doing the work is nevertheless extremely complex and challenging, given the inter-country/cultural context that characterised the IBT role (see Authors). Extra-role and proactive role behaviour, both relational, were also IBT obligations. Extra role behaviour is defined as 'all obligations that fall outside the work-package of duties, such as commitment, being flexible about hours and volunteering to do extra tasks' (Bal et al., 2010: 382). There were numerous examples of this:

(...) I always have something in my suitcase, I say my suitcase but my computer bag is actually my suitcase, and in it there's always a shirt and underwear for one overnight stay. That means I can always go somewhere for one night. And that sometimes happens. (Kevin)

And in similar vein:

Between Christmas Day and New Year, I had a huge problem, a contract of [customer] that could not be delivered. I therefore left on Christmas Eve and I got back at New Year, on New Year's Eve. That was such a major issue, I wasn't able to resolve it from here. They don't celebrate Christmas and New 
Year in [country],. For me, that's... I shouldn't think about it... sure I had to organise it, that's something else. But I shouldn't think about whether or not I'm going to do that.... (Florence)

Here we see a highly relational extensive exchange in which the IBTs work to accommodate organisational demands at, potentially, the expense of their own domestic convenience. The flexible nature of their travelling schedules created an obligation that would not be within a typical expatriate contract. Finally within role behaviour, we surfaced proactive role behaviour which refers to 'the obligations that employees feel in order to enhance the operation of the organisation as a whole' (Bal et al., 2010: 382). Proactive behaviour is considered broader than in-role and extra-role behaviour and is not widely featured in psychological contract literature. Again it is relational as it demonstrates a strong sense of identification with the employer's position. Marc for example suggested that he 'fights for the company' as if married to it in order to 'push it forward'. This links closely to the final employee obligation, loyalty, which was also relational. IBT accounts reflected expectations of long-term open ended employment relationships was envisaged and this was particularly important to them:

I start in every new working partnership with the idea of 'for the rest of my life'. You never know how it's going to go, but I think that's the only way to start out... (Nils)

The IBT's concerned offered their employer a form of security in relation to the potential tem of their employment relationship. Surprisingly, however, the IBTs did not expect employers to reciprocate with a job security obligation: 
I certainly never take my position for granted. And I don't think that's so bad, it doesn't bother me that that's how it is. (Andy)

While lack of job security reflects Belgian research in which a more transactional career trend is observed amongst highly educated employees (Soens et al., 2005), it is at odds with the loyalty displayed by the IBTs.

\section{Employer Obligations}

Of the ten employer obligations identified, seven were relational, two transactional and one lacked clear categorisation, again reflecting a predominantly relational contract. Taking support first, IBT constructions of the obligation varied and related mainly to support while undertaking international assignments. Walter expressed a transactional view in that I want a good bed and a good shower' while Kevin had a more relational interpretation:

And then once you're there, (...) that you're taken care of there, by the host, that you're received in the company as a guest (...). That means that they'll eat with you, they show you where you can go in the area, etc., that you're not left to fend for yourself.

The support obligation expressed by the interviewees is consistent with the importance Mäkelä et al. (2017) attach to this in order to keep satisfaction with work-related travel high. Nevertheless, no IBT suggested that the employer should provide functional support for the IBT's home base or family which again differs from expatriates who desire support in and alongside work for both themselves and their family (Guzzo and Noonan, 1994). 
The flexibility obligation reflects much of the extant literature and ranged from 'adjusting hours in the working day' to 'taking 3 months off to build a house following a period of extensive travel' (Kevin). However, little specific to the IBT role emerged, whereas job content more clearly reflected the nature of IBT role. Central to this was travel, which all IBTs expected and enjoyed provided there was a clear purpose:

That you aren't just travelling to show your face, but that there's also something connected to it... (Cindy)

While there was recognition of potential inconvenience (as substantially illustrated in the study of Baker and Ciuk, 2015), it was also stimulating and Nils suggested that it was something 'he could not do without', albeit within certain boundaries:

It's always like searching for a balance, like at a certain point you also get a feeling of guilt. You know you aren't leaving your wife and three children behind, but I mean dumping all of the week's worries on her, and that's just how it is... (Nils)

This again contrasts with a typical expatriate experience in which the family relocates together. There were other benefits to traveling:

I really like being on aeroplanes, for eight hours or so.... There's no telephone, no computer because you can't get any network, so it's real time for me. I can do a report and for once I can think a long time about it. (Florence) 
This reflection or 'me time' was also suggested to facilitate the proactive role behaviour obligation by creating space to prioritise the company's agenda. The travel obligation linked closely to variety, as IBTs perceived that employers 'really have to continually give you new challenges and satisfaction' (Kevin). This reflects Demel and Mayrhofer (2010) notion of 'getting high (internationally)' which refers to interesting and new job-tasks that must be strategic and international in nature. Cindy reflected powerfully that she would find it 'horrible' having to do the same thing 'for the rest of your days'.

Responsibility, for people or projects, and autonomy, Bill almost 'being his own boss' and being able to work 'without too much control' were both important and relational obligations and broadly reflect extant research.

Development obligations, both vertical and horizontal were identified. Vertical development centred largely on promotion and was seen to be part of a largely economic exchange (Rousseau, 1995). IBTs further recognised that opportunities may be limited given their current seniority. Horizontal development, through perhaps job rotation or assignment of challenging projects (Florence), was more relationally viewed. Interestingly, personal development was both relational and reflective of the IBT role. Personal growth was achieved by both role execution and travel, for example: 
... I want to gain different experiences in my life. I want, when I'm old, to be able to look back onto different experiences, I want to have tried out different things. (Bill)

Sam suggested that international experience was 'enriching' which was supported by Kevin's experiences:

I was in Bahrain, for instance. In Islam you don't shake women's hands. Although they're just in the same office and do the same work as anyone else, they don't shake hands with women. So I didn't know that... a person explains it. You don't feel embarrassed because it's explained to you, and that's really important.... that there's a local person who takes you along and who shows you everything.

Kevin also argued that the intercultural training often offered for expatriate assignments is not required for short international stays provide this local development was available. This contrasts with Mäkelä et al. (2017) who consider cross-cultural education as beneficial for IBTs since they might work in multiple cultures in a rather short amount of time.

The final employer obligation was financial rewards which was, perhaps not surprisingly, transactional in nature. There was substantial emphasis on this in light of the individualised nature of the IBT employment relationship, for example, ‘l have to [emphasised] get paid well.' (Walter)

This related in part to the demanding and open ended nature of the IBT role: 
Er, extremely important. I'll come out with it, I think regarding the role you perform, that you should get for it what is required. Also regarding the travelling, all that working, the number of hours that you do. We don't get an hourly wage, we don't have hours, I think they [the employer] then have to pay enough. (Kevin)

This emphasis on financial obligations reflects the importance of monetary reward within the Belgian context (Sels et al., 2000), although Cindy (like others) suggested that balance was required in that 'For me, what's very important is the job content, more than the actual financial aspect.'

\section{Joint Obligations}

The final four obligations were shared between employer and IBT and, accordingly, were relational in nature. Social atmosphere was important and comprised obligations of family, collegiality and respect and trust. A familial and personal work environment was important, despite the international nature and volatility that characterises the IBT role:

You could describe it [working with colleagues] as a family. It also feels like, everywhere you go you're always welcome, there's very little conflict, it really feels like a family. (Kevin)

Collegiality related to working with people who were stimulating and triggering' (Sam) while respect and trust constituted core obligation for operating professionally. These were linked to both the relationship between colleagues and with the connection with their employer or manager. Florence 
suggested that trust 'on both sides' offered her the possibility to achieve what is best for her and the company. Open relationships were clearly linked to this:

That [social relationship with the employer] is actually an extremely important aspect of my life, if I don't feel right in my job, then yes... for me it certainly isn't just economic, that's of course part of it. (...) The social aspect is definitely important and I'm someone who has to be in a good group. Feeling recognition, not just financially but also getting the feeling of what I do being appreciated and being taken into account... (Nils)

Florence expressed the mutual openness as follows:

They [the employer] know me, they know how I think, they're in so many meetings with me (...) a very open relationship, that's very important for me, being able to have an open discussion. I can't stand having to hide things, or that I can't say things for some reason or another, if there's something I should be able to say it. Straightforward and very open. I'm extremely direct, even towards my employer, otherwise I can't perform this role. That's always with respect. For me, that's also very important.

In summary, the IBT contract portrayed reflects an open-ended relationship with autonomy and a strong sense of responsibility for managing the work contract. Travel, support and financial rewards were also prominent. While predominantly relational, transactional aspects were also obvious in the contract. This observation is not entirely surprising given extant literature 
(Authors; Conway and Briner 2009) but is nevertheless an important contribution to understanding the nature of the IBT psychological contract.

\section{Discussion and Conclusions}

That the IBT psychological contract is predominantly relational is an interesting finding and perhaps contrary to much recent IHRM research. For example, the expatriate psychological contract literature indicates the increasingly transactional nature of international employee psychological contracts (Thomas et al., 2005, Stahl et al., 2009, Pate and Scullion, 2010). Our findings are more reflective of original expatriate studies in which the psychological contract was still principally seen as steeped in relational elements (Guzzo and Noonan, 1994). Wider research on 'boundaryless careerists' also argues for a relational to transactional shift, i.e. from 'old' to 'new' deal (Rousseau, 1995, Hiltrop, 1996). Yet, despite the highly educated, career-focussed nature of our participants, their psychological contracts were still predominantly relational in nature. As well as informing understanding of international employment relations, our findings more widely call into question the extent to which the much-discussed relational/transactional transition has taken place. We support Conway and Briner (2009: 49) who suggest that it is difficult to evaluate whether or not there was an actual transition from an old contract to a new contract because no decent historical data with which to test the proposition are available'.

The Belgian context may also be important, as the mix of both relational and transactional IBT obligations reflects wider Belgian psychological contract research (Sels et al., 2000, De Cuyper et al., 2008). The findings 
also provide strong support for previous research on Belgian high potential employees (Van den Brande et al., 2002, Vloeberghs et al., 2005) whereby the individual assumes a certain responsibility for his/her career and related psychological contract formation. For example, while participants expected the employer to provide growth opportunities, they perceived it to be an IBT responsibility to realise the potential of these opportunities. The IBT also had responsibility for clearly signalling his/her career needs. As Sam stated: 'If you don't say anything yourself, you won't get anything. You have to continually share your thoughts.' Differences between IBT psychological contracts and wider Belgian research did, however, emerge. The job content, (in-/extra-) role behaviour and loyalty obligations, all relationally categorised, are somewhat at odds with typical psychological contract characteristics of Belgian employees (Sels et al., 2000, Soens et al., 2005). While according to Sels et al (2000), the Belgian psychological contract reflects a strong connection between employer and employee, Soens et al (2005) suggest that loyalty is reducing amongst highly educated employees such as IBTs. However our findings evidence a clear role for IBT loyalty, albeit the converse employer obligation, job security, was little in evidence. IBTs did not explicitly voice that the employer must offer them job security which diluted the strong employer/employee connection (Sels et al., 2000).

In conclusion, we argue that our research makes a number of contributions, empirical, theoretical and practical. First and in light of the relative scarcity of focus on non-expatriate international work (Baker and Ciuk, 2015) we contribute empirical data to the IHRM field in developing understanding of a newly emerging form of international employee, the IBT. Further, the adoption of an established concept such as the psychological 
contract contributes to the 'maturing nature of the IHRM as a field of scientific endeavour' (Björkman and Welch, 2015: 136) and serves to develop the scope of its multi-disciplinarity. Second, we contribute to the psychological contract theory. In studying a new employee group, we develop general understanding and additionally inform the unresolved debate on the relational/transactional shift (Conway and Briner, 2009). Contrary to much extant research, we demonstrate the continuing relational nature of many psychological contracts. Further we add to the relatively small body of qualitative psychological contract research, allowing for nuanced and indepth insights into the little-researched IBT group (Gibson and Hanes, 2003). Our findings offer a unique insight into the nature of the IBTs' employment relationship which lays the foundations for further exploration of the IBT psychological contract.

Third, we make a contribution to practice in that our work develops insight into effective management and maximisation of psychological contracts (Rodwell et al., 2015), which is essential to realising IBTs' strategic potential (Tahvanainen et al., 2005). We provide HR practitioners and/or organisations with a rich and expanded understanding of the IBT employment relationship. Insight into IBT perceptions of their employment deal offers the opportunity to tailor it accordingly. For example, job content, support and autonomy are vital within IBT working relationships and assignments. Importantly, we evidence that it was not possible to propose a psychological contract categorisation that was applicable for all of the IBTs in this study, let alone for the entire population given its idiosyncratic, socially constructed nature. This highlights the importance of individual negotiation 
and understanding between IBTs and their managers to ensure the offer of a deal appropriate to that particular IBT. In this way transparent working partnerships that serve to avoid breach of the contract can be established (Robinson and Morrison, 2000). Given both the strategic importance (Mäkelä et al., 2017) and 'marketable' nature of IBTs (Stahl et al., 2009: 92), the understanding developed through our research is extremely valuable to organisations operating internationally wishing to develop and retain their high potential employees (Tahvanainen et al., 2005, Collings et al., 2007, Welch et al., 2007).

We recognise, however, that there is further work to be done. Our findings address only the employee perspective and the employer perspective provides a fruitful avenue for future study. As we noted in our original definition, the psychological contract is bilateral and thus understanding the perspectives of both parties is essential to its effective operation. Further, a larger sample of both IBTs and organisations is required to confirm and build upon our work. Finally, we note that we have adopted a content approach to our investigation while others have called for use of process perspectives to further develop understanding (Conway and Briner, 2009). Such future research would also provide a valuable complementary perspective to our findings.

\section{References}


AGARWAL, U. \& GUPTA, R. 2018. Examining the Nature and Effects of Psychological contract: Case Study of an Indian Organization. Thunderbird International Business Review, 60, 175-191.

BAKER, C. \& CIUK, S. 2015. Keeping the family side ticking along: An exploratory study of the work-family interface in the experiences of rotational assignees and frequent business travellers. Journal of Global Mobility, 3, 137-154.

BAL, P., JANSEN, P., VAN DER VELDE, M., DE LANGE, A. \& ROUSSEAU, D. 2010. De rol van toekomstperspectief in het psychologisch contract van oudere werknemers. Maandblad voor Accountancy en Bedrijfseconomie, 84, 381-394.

BEAVERSTOCK, J., DERUDDER, B., FAULCONBRIDGE, J. \& WITLOX, F. 2010. International Business Travel and the Global Economy: Setting the Context. In: BEAVERSTOCK, J., DERUDDER, B., FAULCONBRIDGE, J. \& WITLOX, F. (eds.) International Business Travel in the Global Economy. Farnham: Ashgate Publishing Limited.

BJÖRKMAN, I., STAHL, G. \& MORRIS, S. 2012. Introduction. In: STAHL, G., BJÖRKMAN, I. \& MORRIS, S. (eds.) Handbook of research in international human resource management. 2nd ed. Cheltenham: Edward Elgar Publishing Limited.

BJÖRKMAN, I. \& WELCH, D. 2015. Framing the field of international human resource management research. International Journal of Human Resource Management, 26, 136-150.

CHAMBEL, M., LORENTE, L., CARVALHO, V. \& MARTINEZ, I. 2016. Psychological contract profiles among permanent and temporary agency workers. Journal of Managerial Psychology, , 20, 79-94.

COLLINGS, D., MCDONNELL, A. \& MCCARTER, A. 2015. Types of international assignees, Oxon, Routledge.

COLLINGS, D., SCULLION, H. \& MORLEY, M. 2007. Changing patterns of global staffing in the multinational enterprise: Challenges to the conventional expatriate assignment and emerging alternatives. Journal of World Business, 42, 198-213.

CONWAY, N. \& BRINER, R. 2009. Understanding Psychological Contracts at Work: A Critical Evaluation of Theory and Research, Oxford, Oxford University Press.

COYLE-SHAPIRO, J. \& CONWAY, N. 2010. The Employment Relationship through the Lens of Social Exchange. In: COYLE-SHAPIRO, J., SHORE, L., TAYLOR, M. \& TETRICK, L. (eds.) The Employment Relationship. Examining Psychological and Contextual Perspectives. Oxford:: Oxford University Press.

COYLE-SHAPIRO, J. \& PARZEFALL, M. 2008. Psychological contracts. In: COOPER, C. \& BARLING, J. (eds.) he SAGE handbook of organizational behavior. London: Sage.

DE CUYPER, N., RIGOTTI, T., DE WITTE, H. \& MOHR, G. 2008. Balancing psychological contracts: Validation of a typology. International Journal of Human Resource Management, 19, 543-561.

DE MEUSE, K., BERGMANN, T. \& LESTER, S. 2001. An investigation of the relational components of the psychological contract across time, generation and employment status. Journal of Managerial Issues, 13, 102-188. 
DEMEL, B. \& MAYRHOFER, W. 2010. Frequent Business Travelers Across Europe: Career Aspirations and Implications. Thunderbird International Business Review, 52, 301-311.

ESPINO, C., SUNDSTROM, S., FRICK, H., JACOBS, M. \& PETERS, M. 2002. International business travel: impact on families and travellers. Occupational and Environmental Medicine, 59, 309-322.

GIBSON, S. \& HANES, L. 2003. he Contribution of Phenomenology to HRD Research. Human Resource Development Review, 2, 181-205.

GUEST, D. 1998. Is the psychological contract worth taking seriously. Journal of Organizational Behavior, 19, 649-664.

GUZZO, R. \& NOONAN, K. 1994. Human resources practices as communications and the psychological contract. Human Resource Management, 33, 447-462.

HARVEY, M., HARTMANN, L., MAYERHOFER, H. \& MOELLER, M. 2010. Corralling the 'Horses' to Staff the Global Organization of 21st Century. Organizational Dynamics, 39, 258-268.

HERRIOT, P., MANNING, W. \& KIDD, J. 1997. The content of the psychological contract. British Journal of Management, 8, 151-162.

HILTROP, J. 1996. Managing the changing psychological contract. Employee Relations, 18, 36-50.

KVALE, S. \& BRINKMANN, S. 2009. Interviews. Learning the craft of qualitative research interviewing (second edition, Thousand Oaks, SAGE.

MACLEAN, M., HARVEY, C. \& CHIA, R. 2011. Sensemaking, storytelling and the legitimization of elite business careers. Human Relations, 65, 17-40.

MACNEIL, I. 1985. Relational contract: what we do and do not know. Wisconsin Law Review, 483-525.

MAKELA, L., KINNUNUN, U. \& SUUTARI, V. 2015. Work-to-life conflict and enrichment among international business travelers: the role of international career orientation. Human Resource Management, 54, 517-531.

MÄKELÄ, L., SAARENPAA, K. \& MCNULTY, Y. 2017. International business travellers, short-term assignees and international commuters. In: MCNULTY, Y. \& SELMER, J. (eds.) Research Handbook of Expatriates. Edward Elgar Publishing.

MASON, M. 2010. Sample Size and Saturation in PhD Studies Using Qualitative Interviews. Forum Qualitative Sozialforschung / Forum: Qualitative Social Research, 11, http://nbnresolving.de/urn:nbn:de:0114-fas100387 [accessed 24/02/2013].

MAYERHOFER, H., HARTMANN, L., MICHELITSCH-RIEDL, G. \& KOLLINGER, I. 2004. Flexpatriate assignments: a neglected issue in global staffing. International Journal of Human Resource Management, 15, 1,371-1,389.

MEYSKENS, M., VON GLINOW, M., WERTHER, W. J. \& CLARKE, L. 2009. The paradox of international talent: alternative forms of international assignments. International Journal of Human Resource Management, 20, 1,439-1,450.

MILES, M. \& HUBERMAN, A. 1994. An Expanded Sourcebook. Qualitative data analysis, Thousand Oaks, Sage. 
OECD. 2013. Better Life Index [Online]. Available:

http://www.oecdbetterlifeindex.org/countries/belgium/ [Accessed 19 April 2014].

PATE, J. \& SCULLION, H. 2010. The changing nature of the traditional expatriate psychological contract. Employee Relations, 32, 56-73.

PATE, J. \& SCULLION, H. 2017. The flexpatriate psychological contract: a literature review and future research agenda. International Journal of Human Resource Management, DOI 10.1080/09585192.2016.1244098

PETROVIC, J., HARRIS, H. \& BREWSTER, C. 2000. CReME Research Report 1/00: new forms of international working [Online]. https://dspace.lib.cranfield.ac.uk/bitstream/1826/3702/3/New forms of international working-2000.pdf. [Accessed 23 Aoril 2011].

ROBINSON, S., KRAATZ, M. \& ROUSSEAU, D. 1994. Changing obligations and the pyschological contract: a longitudinal study. Academy of Management Journal, 37, 137-152.

ROBINSON, S. \& MORRISON, E. 2000. The development of psychological contract breach and violation: a longitudinal study. Journal of Organizational Behavior, 21, 525-546.

RODWELL, J., ELLERSHAW, J. \& FLOWER, R. 2015. Fulfill psychological contract promises to manage in-demand employees. Personnel Review, 44, 689 - 701.

ROUSSEAU, D. 1995. Understanding psychological contracts, London, Sage.

ROUSSEAU, D. \& SCHALK, R. 2000. Psychological contracts in employment. Cross-national perspectives, Thousand Oaks, Sage.

SELS, L., JANSSENS, M., VAN DEN BRANDE, I. \& B., O. 2000. Belgium: A Culture of Compromise. In: ROUSSEAU, D. \& SCHALK, R. (eds.) Psychological contracts in employment: Cross-national perspectives. Thousand Oaks: Sage.

SHAFFER, M., KRAIMER, M., CHEN, Y. \& BOLINO, M. 2012. Choices, Challenges, and Career Consequences of Global Work Experiences: A Review and Future Agenda. Journal of Management, 38, 1,282$1,327$.

SLEEUWAEGEN, L. \& PEETERS, C. 2012. Belgium in the new global economy: Export and international sourcing [Online]. Available: http://www.beinternational.be/nl/publications [Accessed 26 November 2012].

SMITH, J., FLOWERS, P. \& LARKIN, M. 2009. Interpretative Phenomenological Analysis. Theory, Method and Research, London, Sage.

SOENS, N., DE VOS, A., BUYENS, D., HEYLEN, L., KUPPENS, A., VAN PUYVELDE, I. \& MORTELMANS, D. 2005. Belgische loopbanen in kaart: traditioneel of transitioneel? Eindrapport van het onderzoek naar "het begrip loopbaan", Gent, Academia Press.

STAHL, G., CHUA, C., CALIGIURI, P., CERDIN, J. \& TANIGUCHI, M. 2009. Predictors of turnover intentions in learning-driven and demand-driven international assignments: the role of repatriation concerns, satisfaction with company support, and perceived career advancement opportunities. Human Resource Management, 48, 89-109. 
TAHVANAINEN, M., WELCH, D. \& WORM, V. 2005. Implications of Shortterm International Assignments. European Management Journal, 23, 663-673.

TAYLOR, M. \& TEKELAB, A. 2010. Taking Stock of Psychological Contract Research: Assessing Progress, Addressing Troublesome Issues, and Setting Research Priorities. In: COYLE-SHAPIRO, J., SHORE, L., TAYLOR, M. \& TETRICK, L. (eds.) The Employment Relationship. Examining Psychological and Contextual Perspectives. Oxford: Oxford University Press.

TETRICK, L. 2010. Understanding the Employment Relationship: Implications for Measurement and Research Design. In: COYLESHAPRIO, J., SHORE, L., TAYLOR, M. \& TETRICK, L. (eds.) The Employment Relationship. Examining Psychological and Contextual Perspectives. Oxford: OUP.

THOMAS, D., LAZAROVA, M. \& INKSON, K. 2005. Global careers: New phenomenon or new perspectives? Journal of World Business, 40, 340-347.

VAN DEN BRANDE, I., JANSSENS, M., SELS, L. \& OVERLAET, B. 2002. Psychologische contracten in Vlaanderen. Over Werk Tijdschrift van het Steunpunt WAV, 15, 171-175.

VAN MANEN, M. 1990. Researching Lived Experience. Human Science for an Action Sensitive Pedagogy, Albany, N.Y., State University of New York.

VLOEBERGHS, D., PEPERMANS, R. \& THIELEMANS, K. 2005. Highpotential development policies: an empirical study among Belgian companies. Journal of Management Development, 24, 546-558.

WELCH, D., WELCH, L. \& WORM, V. 2007. The international business traveller: a neglected but strategic human resource. International Journal of Human Resource Management, 18, 173-183.

WELCH, D. \& WORM, V. 2006. International business travellers: a challenge for IHRM. In: STAHL, G. \& BJÖRKMAN, I. (eds.) Handbook of research in international human resource management. Cheltenham: Edward Elgar Publishing Limited.

YAN, A., ZHU, G. \& HALL, D. 2002. International Assignments for Career Building: A Model of Agency Relationships and Psychological Contracts. Academy of Management Review, 27, 373-391. 
Table 1: Nature of obligations within the psychological contract

\begin{tabular}{|c|c|c|c|}
\hline $\begin{array}{c}\text { TRANSACTIONAL } \\
\text { EMPLOYER } \\
\text { OBLIGATIONS }\end{array}$ & $\begin{array}{c}\text { TRANSACTIONAL } \\
\text { EMPLOYEE } \\
\text { OBLIGATIONS }\end{array}$ & $\begin{array}{l}\text { RELATIONAL } \\
\text { EMPLOYER } \\
\text { OBLIGATIONS }\end{array}$ & $\begin{array}{l}\text { RELATIONAL } \\
\text { EMPLOYEE } \\
\text { OBLIGATIONS }\end{array}$ \\
\hline $\begin{array}{l}\text { - Advancement } \\
\text { - High pay } \\
\text { - Merit pay }\end{array}$ & $\begin{array}{l}\text { - Notice } \\
\text { - Transfers } \\
\text { - No competitor } \\
\text { support } \\
\text { - Proprietary } \\
\text { protection } \\
\text { - Minimum stay }\end{array}$ & $\begin{array}{l}\text { - Training } \\
\text { - Job security } \\
\text { - Development } \\
\text { - Support }\end{array}$ & $\begin{array}{l}\text { - Overtime } \\
\text { - Loyalty } \\
\text { - Extra-role } \\
\text { behaviour }\end{array}$ \\
\hline
\end{tabular}

Table 2: Profile of Participants

\begin{tabular}{|c|c|c|c|c|c|}
\hline PSEUDONYM & JOB TITLE & AGE & $\begin{array}{l}\text { APPROXIMATE } \\
\text { \% OF TIME } \\
\text { SPENT } \\
\text { ABROAD }\end{array}$ & $\begin{array}{l}\text { BUSINESS ACTIVITY } \\
\text { OF THE RESEARCH } \\
\text { PARTICIPANT'S } \\
\text { EMPLOYER }\end{array}$ & $\begin{array}{c}\mathbf{N}^{\circ} \text { OF } \\
\text { EMPLOYEES }\end{array}$ \\
\hline Nils & $\begin{array}{l}\text { Sales } \\
\text { Manager }\end{array}$ & 37 & 30 & $\begin{array}{l}\text { Production of } \\
\text { (laminate/wooden) } \\
\text { flooring-solutions, } \\
\text { panels and roofing } \\
\text { elements }\end{array}$ & $\begin{array}{l}4,000 \\
\text { (world- } \\
\text { wide) }\end{array}$ \\
\hline Cindy & $\begin{array}{l}\text { Global } \\
\text { Category } \\
\text { Manager }\end{array}$ & 31 & 15 & $\begin{array}{l}\text { Steel wire } \\
\text { transformation and } \\
\text { manufacturing of } \\
\text { coatings }\end{array}$ & $\begin{array}{l}27,000 \\
\text { (world- } \\
\text { wide) }\end{array}$ \\
\hline Bill & $\begin{array}{l}\text { Senior } \\
\text { Consultant }\end{array}$ & 40 & $15-20$ & $\begin{array}{l}\text { Business (IT) } \\
\text { consulting }\end{array}$ & $\begin{array}{l}750 \\
\text { (Belgium) }\end{array}$ \\
\hline Kevin & $\begin{array}{l}\text { Solution } \\
\text { Integration } \\
\text { Manager }\end{array}$ & 35 & 80 & $\begin{array}{l}\text { Production of } \\
\text { compressors, } \\
\text { construction and } \\
\text { mining equipment, } \\
\text { power tools and } \\
\text { assembly systems }\end{array}$ & $\begin{array}{l}35,000 \\
\text { (world- } \\
\text { wide) }\end{array}$ \\
\hline Sam & $\begin{array}{l}\text { Export } \\
\text { Manager }\end{array}$ & 35 & 40 & $\begin{array}{l}\text { Production of } \\
\text { kitchen and bath } \\
\text { linen }\end{array}$ & $\begin{array}{l}200 \\
\text { (Belgium) }\end{array}$ \\
\hline Florence & $\begin{array}{l}\text { Import } \\
\text { Director - } \\
\text { Mgt. }\end{array}$ & 42 & $10-15$ & $\begin{array}{l}\text { Production of } \\
\text { kitchen and bath }\end{array}$ & $\begin{array}{l}200 \\
\text { (Belgium) }\end{array}$ \\
\hline
\end{tabular}




\begin{tabular}{|l|l|l|l|l|l|}
\hline & $\begin{array}{l}\text { Committee } \\
\text { member }\end{array}$ & & & linen & \\
\hline Marc & $\begin{array}{l}\text { Export } \\
\text { Sales } \\
\text { Manager }\end{array}$ & 29 & 40 & $\begin{array}{l}\text { Production of } \\
\text { linen/fabrics for } \\
\text { upholstery and } \\
\text { curtains }\end{array}$ & $\begin{array}{l}24 \\
\text { (Belgium) }\end{array}$ \\
\hline Andy & $\begin{array}{l}\text { Business } \\
\text { Analyst - } \\
\text { Corporate } \\
\text { Mgt. Team } \\
\text { member }\end{array}$ & 28 & 50 & $\begin{array}{l}\text { Heavy lifting } \\
\text { manufacturing and } \\
\text { engineered transport }\end{array}$ & $\begin{array}{l}3,000 \\
\text { (world- } \\
\text { wide) }\end{array}$ \\
\hline Walter & $\begin{array}{l}\text { Technical } \\
\text { Manager }\end{array}$ & 40 & 10 & $\begin{array}{l}\text { Glass mould } \\
\text { manufacturing }\end{array}$ & $\begin{array}{l}3,500 \\
\text { (spread } \\
\text { over 6 } \\
\text { sites in } \\
\text { the EU } \\
\text { and 1 in } \\
\text { the US) }\end{array}$ \\
\hline
\end{tabular}

Table 3: Summary of contract obligations categorised according to nature

\begin{tabular}{|c|c|}
\hline EMPLOYER OBLIGATIONS & EMPLOYEE OBLIGATIONS \\
\hline & Role behaviour: \\
\hline
\end{tabular}




\begin{tabular}{|c|c|}
\hline & $\begin{array}{r}\text { (1) in-role behaviour: transactional } \\
\text { (2) extra-role behaviour: relational }\end{array}$ \\
$\begin{array}{c}\text { (3) proactive role behaviour: relational } \\
\text { (4) Support: transactional/relational }\end{array}$ & \\
\hline (5) Flexibility: relational & \\
(6) responsibility: relational & \\
(7) travel: relational & \\
(8) variety: relational & \\
(9) Autonomy: relational & \\
Development: & (11) vertical: transactional \\
(12) horizontal: relational \\
(13) personal: relational
\end{tabular}

Social atmosphere:

(14) family: relational

(15) work atmosphere - collegiality: relational

(16) respect and trust: relational

(17) Financial rewards: transactional

(18) Open relation: relational 